\title{
HEAVY METALS IN URBAN PARK SOILS FROM ATHENS, GREECE
}

\section{Papazotos P. ${ }^{1,2}$, Chalkiadaki O. ${ }^{1,3}$, Chatzistamatiou E.A. ${ }^{1}$, Georgopoulos G. ${ }^{1}$, Gkiouleka I. ${ }^{1}$, Katsikis I. ${ }^{1}$, Zygouri E. ${ }^{1}$, Kelepertzis E. ${ }^{1}$ and Argyraki A. ${ }^{1}$}

${ }^{I}$ National and Kapodistrian University of Athens, Faculty of Geology and Geoenvironment, Panepistimiopolis, Zographou, 15784, Athens, Greece,argyraki@geol.uoa.gr, lina_chatzistamatiou@hotmail.com,giorgos_georgopoulos@hotmail.com, ireneski08@hotmail.com,johnkatsikis91@gmail.com,kelepert@geol.uoa.gr, eva12591@gmail.com

${ }^{2}$ National Technical University of Athens, School of Mining \& Metallurgical Engineering, Heroon Polytechniou Str. 9, Zographou,15780, Athens, Greece, papazotos@metal.ntua.gr

${ }^{3}$ National and Kapodistrian University of Athens, Department of Chemistry, Panepistimiopolis, Zographou, 15441, Athens, Greece, ochalkiadaki@chem.uoa.gr

\begin{abstract}
Urban geochemistry is a scientific discipline which is growing in the recent years mainly because of the environmental impact caused by urbanization. The present study aims to determine the concentrations of potentially harmful elements (PHES) on surface soils $(0-10 \mathrm{~cm})$ in Athens parks. Soil sampling was carried out in public park areas within the Athens urban area. Twenty surface soil $(0-10 \mathrm{~cm})$ samples were collected and the $<100 \mu m$ grain size fraction was analyzed by Flame Atomic Absorption Spectroscopy for $\mathrm{Pb}, \mathrm{Zn}, \mathrm{Ni}, \mathrm{Cu}, \mathrm{Mn}$ and $\mathrm{Cr}$ after a strong acid dissolution and partial extraction by $1 \mathrm{M} \mathrm{HCl}$. The organic soil matter content was determined by a combustion method. Two different inter-correlated groups of elements were identified, one including $\mathrm{Pb}, \mathrm{Zn}, \mathrm{Cu}$ showing the anthropogenic signature on urban soil and another including $\mathrm{Cr}, \mathrm{Ni}$ and Mn showing geogenic origin. The mobility of the heavy metals determined in the present study follows the decreasing order: $\mathrm{Pb}>$ $M n>N i \approx C u \approx Z n>C r$. The data indicate that park areas seem to be important sinks of anthropogenic elements in urban soils.
\end{abstract}

Keywords: Geochemistry, environmental pollution, potentially harmful elements.

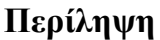

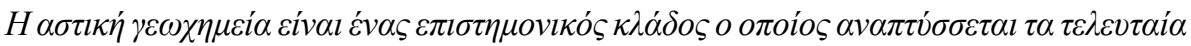

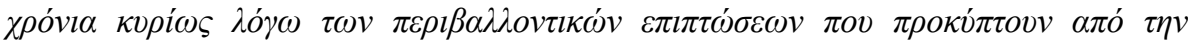

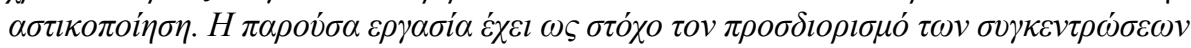

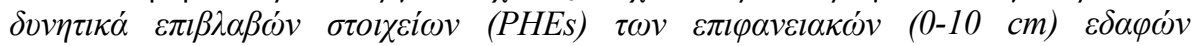

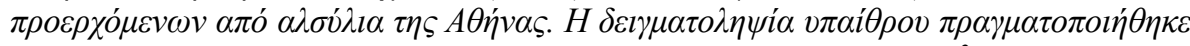

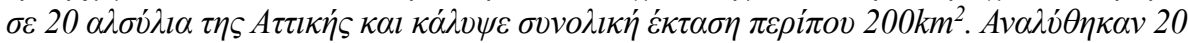

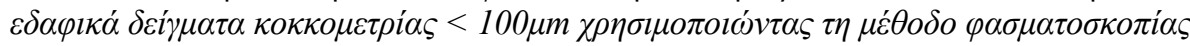

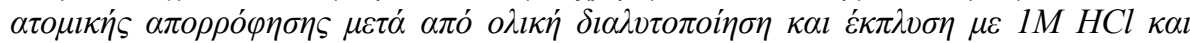

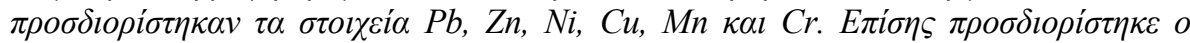

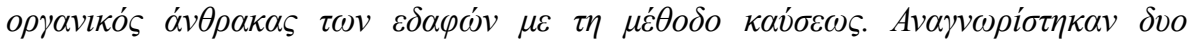




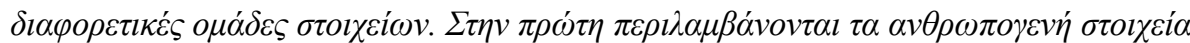

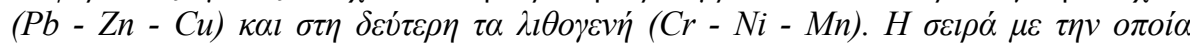

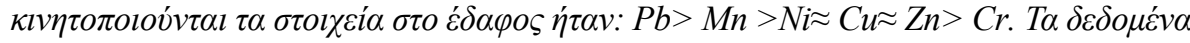

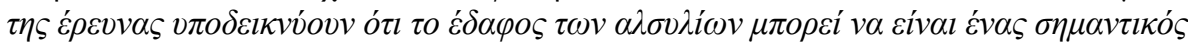

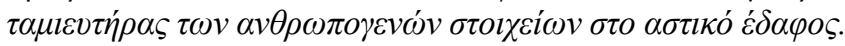

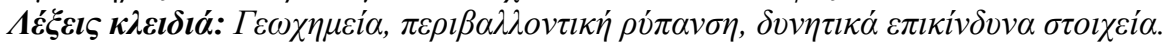

\section{Introduction}

Soils of urban environment represent an integral part of the city landscape, with different and unique characteristics compared to the naturally developed soils (Wong et al., 2006). Furthermore they receive higher than normal loads of contaminants from traffic and industrial activity, rapid development and urbanization (Yaylali-Abanuz, 2011). However, several studies have emphasized the influence of natural geochemical factors on soil chemistry in strongly urbanized regions (e.g., Argyraki and Kelepertzis, 2014).

Potentially harmful elements (PHE's) including heavy metals and metalloids, are among the most tenacious soil pollutants because of their non-biodegradable nature and the long term toxicity (Ajmone-Marsan and Biasioli, 2010; Massas et al., 2013; Kelepertzis and Stathopoulou, 2013). Urban soils especially in public park areas may have an immediate impact on public health, mainly due to the direct contact with humans (Mielke et al., 1999). In particular, the ingestion of dust and soil has been widely regarded as one of the key pathways by which children are exposed to the heavy metals and metalloids from paint, leaded gasoline, vehicles and local industry (Rasmussen et al., 2001). Researchers found positive correlation between urban soil heavy metals concentration and intensive urbanization metrics (e.g., urban population density, length of roads and highways, traffic volume, and percent urban land use) (Pouyat et al., 2008). Consequently, the highest concentrations of the classical urban contaminants, found in Athens, were observed in the surface soil from roadside verges and in the older parts of the city, as well as the densely populated areas (Argyraki and Kelepertzis, 2014).

Athens is the Capital city of Greece and has one third of its population (around 3,000,000 city residents). Significantly higher concentrations of $\mathrm{Pb}$ have been previously observed in parks and woodland areas compared to other land uses in Athens (Argyraki and Kelepertzis, 2014). Following this, the central hypothesis of the present study is that vegetated, grove areas of Athens influence the concentration levels and the environmental mobility of heavy metals in urban soil. The specific objectives of this paper were: (a) to assess the concentration of heavy metals ( $\mathrm{Pb}, \mathrm{Zn}, \mathrm{Ni}, \mathrm{Cu}, \mathrm{Mn}$, $\mathrm{Cr}$ ) in soil samples from 20 urban parks in Athens and (b) to investigate the availability of heavy metals by performing a single chemical extraction test using $1 \mathrm{M} \mathrm{HCl}$.

\section{Materials and Methods}

\subsection{Soil Sampling}

The target areas where soil sampling was performed were parks and specifically grove areas within the city of Athens. A common characteristic of all sampling areas is the presence of pine trees. A total of twenty composite topsoil $(0-10 \mathrm{~cm})$ samples were collected during the spring of 2015 from locations presented in Figure 1. At each sampling site, one composite sample was collected by mixing five subsamples from the corners and the center of a $10 \mathrm{~m}$ square in sealable plastic bags. Samples were collected using a plastic spatula after removing debris and surface vegetation.

\subsection{Laboratory procedures}

The analytical experimental work presented below was performed at the Laboratory of Economic Geology and Geochemistry (Faculty of Geology and Geoenvironment, University of Athens) and the Laboratory of Environmental Chemistry (Faculty of Chemistry, University of Athens). All 
samples were air dried at a constant temperature of $50^{\circ} \mathrm{C}$ for 3 days in a thermostatically controlled oven. They were subsequently gently disaggregated in a porcelain mortar and sieved to $2 \mathrm{~mm}$ fraction. Each soil sample was further sieved through a nylon $100 \mu \mathrm{m}$ sieve in order to focus on geochemically reactive particles and stored at room temperature in a dark storeroom. The $100 \mu \mathrm{m}$ fraction was used for chemical analysis. All utensils were thoroughly cleaned between the samples to avoid cross contamination.

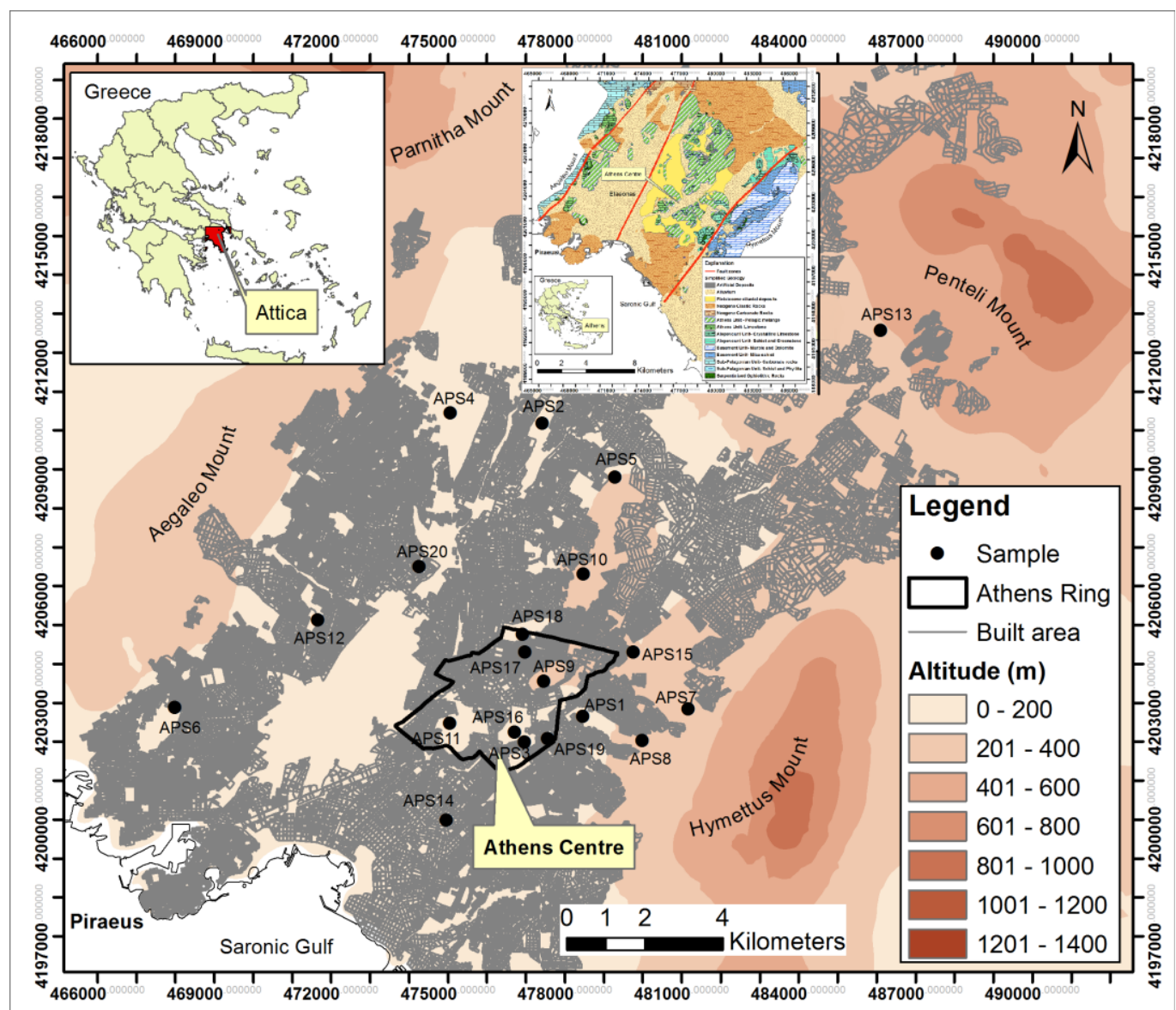

Figure 1 - Map of sampling locations. APS1: Ilissia "Black Grove", APS2: Nea Philadelphia Grove, APS3: National Garden, APS4: Tritsis Park, APS5: Veikos Park, APS6: Dexameni Park, APS7: NTUA Campus, APS8: NKUA Campus, APS9: Lycabettus Hill, APS10: Attikon Park, APS11: Filopappos Hill, APS12: Aegaleo Park, APS13: Syggros Park, APS14: Nea Smyrni Grove, APS15: Park of Hellenic Army, APS16: Ardittos Hill, APS17: Strefi Hill, APS18: Pedion Areos, APS19: Pagrati Grove, APS20: AUA Campus.

\subsubsection{Chemical analysis}

The total heavy metal content of the soil was determined after acid digestion with a mixture of three concentrated acids $\left(\mathrm{HNO}_{3}-\mathrm{HClO}_{4}-\mathrm{HF}\right)$ in Teflon beakers according to ISO 14869-1:2000 method. The digests were diluted appropriately with Milli-Q water and stored in polyethylene bottles at $4{ }^{\circ} \mathrm{C}$ until measurement. All glassware and bottles used during the experiments were acid-washed in $10 \%$ nitric acid for at least 24 hours before use. It is noted that the mixture of acids that was used is regarded near total for some elements like $\mathrm{Cr}$ which is usually present in refractory minerals like chromite that is not completely dissolved. 
A portion of the samples was subjected to $1 \mathrm{M} \mathrm{HCl}$ extraction by shaking the samples for 18 hours at room temperature, in order to estimate the availability of the heavy metals, since metal content extracted by this treatment is considered to be easily mobilised and has major environmental significance. Single extractions can be considered as tools indicating potential release of elements from particular soil constituents to which they are associated. Soil washing with acids such as $\mathrm{HCl}$ relies on ion exchange and dissolution of soil components/discrete metal compounds to extract metals. Digestion in $1 \mathrm{M} \mathrm{HCl}$ does not dissolve the silicate matrix. Such reagents do not mobilize trace elements from silicate parent materials but dissolve metal pollutants which largely enter the soil environment in non-silicate bound forms. The $1 \mathrm{M} \mathrm{HCl}$ extractable metal content is commonly used for first-level screening in the risk assessment process, the rational being that total metal analysis includes all non-residual metals as well as metals in the silicate mineral matrix, which are not available to biota under normal environmental conditions (Massas et al., 2010).

Concentrations of $\mathrm{Pb}, \mathrm{Zn}, \mathrm{Ni}, \mathrm{Cu}, \mathrm{Mn}$ and $\mathrm{Cr}$ for all the samples were measured by flame atomic absorption spectroscopy (FAAS), Perkin Elmer 110B, at the Laboratory of Economic Geology and Geochemistry, University of Athens. Analytical quality control for the strong acid digestion was assessed by including one reference material (NIST SRM2711) in the analytical batch for the estimation of analytical bias and performing duplicate analysis on 5 randomly selected samples for the estimation of analytical precision. Duplicate analysis of five randomly selected soil samples was also performed during the $1 \mathrm{M} \mathrm{HCl}$ extraction to estimate analytical precision. The analytical quality of the result was found within acceptable limits.

\subsubsection{Measurement of soil organic carbon}

The organic matter content of the soil samples was estimated by the loss-on-ignition (LOI) method (US-EPA, 2002). The method is semi-quantitative and involves the heated destruction of all organic matter in the soil. A known weight of each sample (1g) was placed in a ceramic crucible which was then heated to $450^{\circ} \mathrm{C}$ for 4 hours in a furnace oven. The samples were then cooled in a desiccator and weighed. Organic matter content was calculated as the difference between the initial and final sample weights divided by the initial sample weight times $100 \%$. All weights were corrected for moisture/water content prior to organic matter content calculation. Since the method determines the organic matter content in the soil, a conversion factor of 1.724 has been used to convert organic matter to organic carbon based on the assumption that organic matter contains $58 \%$ organic $\mathrm{C}$ (i.e., g organic matter/1 .724= g organic C).

\section{Results and Discussion}

\subsection{Total metal content}

The total concentrations of heavy metals are presented in Table 1 along with a comparison with concentrations reported in older surveys from Athens and other cities of Europe. Heavy metal concentrations show positively skewed distributions. Manganese, $\mathrm{Cr}$ and $\mathrm{Ni}$ display the highest concentrations while the widest spread range is observed for $\mathrm{Pb}$ and $\mathrm{Zn}$ (Fig. 2). The concentrations of heavy metals from the studied parks are higher than the ones from Athens' soil (Argyraki and Kelepertzis, 2014) and also higher than the ones from Athens' playground top soil (Massas et al., 2010) for $\mathrm{Ni}, \mathrm{Cu}, \mathrm{Mn}$ and $\mathrm{Cr}$. In comparison with other environmental pollution studies for park areas, e.g. Madrid et al., 2002; Lacatucu et al., $2007 \mathrm{Cr}, \mathrm{Ni}$ and $\mathrm{Mn}$ are enriched in Athens. This might be attributed to the high geochemical background of these elements in Athens soil which is related to the presence of serpentinized ophiolithic rocks in local geology (Argyraki and Kelepertzis, 2014). Metal concentrations are relatively uniform with respect to the studied parks, with the exception of samples collected in the National Garden (APS 3) and Ardittos Hill (APS 16) which present statistically significantly higher values in all heavy metals than the other parks (one way ANOVA, $\mathrm{p}<0.05$, Post hoc tests Tukey and Bonferroni). 


\subsection{Concentrations extracted by $1 \mathrm{M} \mathrm{HCl}$}

In order to evaluate the degree of mobility of heavy metals in the soil samples from park areas, a single chemical extraction test was performed using $1 \mathrm{M} \mathrm{HCl}$. Trace elements accumulate in soil in various forms: water soluble, exchangeable, oxide-bound, carbonate-bound, organic matter- bound, and residual that is bound to resistant minerals (silicates) and non-extractable. The metals present in these forms have different mobility and bioavailability. Water-soluble and exchangeable fractions are readily released to the environment, but the residual fractions are immobile under natural conditions.

Table 1 and Figure 2(b) show the median values and the ranges of extractable metal concentrations respectively. Metal extractability expressed as the percentage of the metal fraction extracted by $1 \mathrm{M}$ $\mathrm{HCl}$ relative to the heavy metal content after total digestion is presented in Figure 3. The results show that extractable amounts of heavy metals by $1 \mathrm{M} \mathrm{HCl}$ (as mean values) are $<5 \%$ for $\mathrm{Zn}$, Ni and $\mathrm{Cu}$, around $10 \%$ for $\mathrm{Mn}$ and $14 \%$ for $\mathrm{Pb}$. The percentages in the soil samples of the extracted $\mathrm{Mn}$ and $\mathrm{Pb}$ presented the highest range (3.4-24\%). The order of heavy metals' potential for release from the studied soils into the dilute acid solution is $\mathrm{Pb}>\mathrm{Mn}>\mathrm{Ni} \approx \mathrm{Cu} \approx \mathrm{Zn}>\mathrm{Cr}$ (one way ANOVA, $\mathrm{p}<0.05$, Post hoc tests Tukey and Bonferroni). The decreasing order of the extractability ratios is in accordance with Kelepertzis and Argyraki (2015) and Lafuente et al. (2008).

Table 1 - Comparison of median values of extractable and total concentrations of heavy metals $\left(\mathrm{mg} \mathrm{kg}^{-1}\right)$ from this study with total heavy metal concentrations $\left(\mathrm{mg} \mathrm{kg}^{-1}\right)$ in park areas from other European cities.

\begin{tabular}{|c|c|c|c|c|c|c|}
\hline & $\mathbf{P b}$ & $\mathbf{Z n}$ & $\mathbf{N i}$ & $\mathbf{C u}$ & Mn & $\mathbf{C r}$ \\
\hline $1 \mathrm{M} \mathrm{HCl}$ extractable & 9.8 & 3.2 & 6.8 & 1.8 & 55 & 2.0 \\
\hline Total concentration & 59 & 105 & 166 & 44 & 603 & 270 \\
\hline Athens soils, $2014^{1}$ & 45 & 98 & 102 & 39 & 554 & 141 \\
\hline Athens playground top soils, $2010^{2}$ & 101 & 146 & 78 & 42 & 311 & 84 \\
\hline Seville $^{3}$ (Mean) & 137 & 145 & 22 & 68 & 471 & 39 \\
\hline Rostock $^{3}$ (Mean) & 83 & 100 & 30 & 35 & - & 48 \\
\hline Madrid $^{3}$ (Mean) & 161 & 210 & 14 & 72 & 437 & 75 \\
\hline Bucharest $^{4}$ (Mean) & 11 & 59 & 21 & 14 & - & 18 \\
\hline Baia Mare $^{4}$ (Mean) & 627 & 508 & 25 & 165 & - & 25 \\
\hline Target value $^{5}$ & 85 & 140 & 35 & 36 & - & 100 \\
\hline Intervention value $^{5}$ & 530 & 720 & 210 & 190 & - & 380 \\
\hline
\end{tabular}

${ }^{1}$ Argyraki and Kelepertzis, 2014; ${ }^{2}$ Massas et al., 2010; ${ }^{3}$ Madrid et al., 2002; ${ }^{4}$ Lacatucu et al., 2007; ${ }^{5}$ VROM, 2000.

The low extractabilities of $\mathrm{Zn}$ and $\mathrm{Cu}$ are in accordance with findings by other researchers (Kelepertzis and Argyraki, 2015; Gasparatos et al., in press) who determined a large residual pool of these metals in Athens' soils. The low lability of $\mathrm{Ni}, \mathrm{Cu}, \mathrm{Zn}$ and $\mathrm{Cr}$ suggest that these contaminants in Athens park soils are sequestered in rather immobile fractions. Manganese is characterized by relatively high extractability probably due to the presence of Mn oxides in soils that are unstable under slightly acidic conditions. Also the relatively high extractability of $\mathrm{Pb}$ is could be at least partially related to its affinity to Mn-oxide phases as previously observed in Athens' soil by Kelepertzis and Argyraki, 2015. 


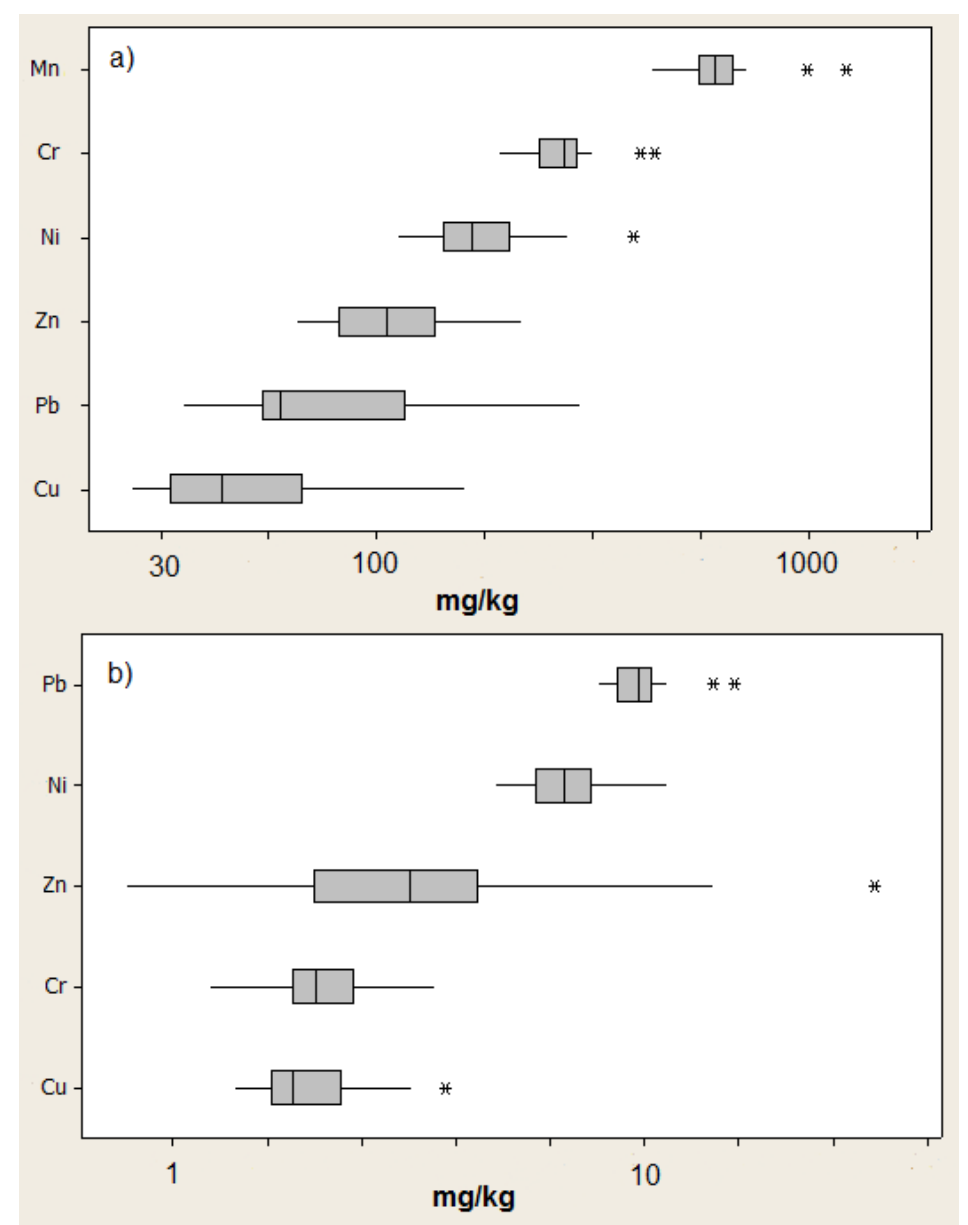

Figure 2 - Boxplot comparison of heavy metal concentrations and variation in the studied samples (log-transformed data) for a) total dissolution and b) $1 \mathrm{M} \mathrm{HCl} \mathrm{extraction.} \mathrm{The}$ elements are ordered according to decreasing median value (vertical lines). The scale is back transformed to show concentrations in $\mathrm{mg} \mathrm{kg}^{-1}$.

\subsection{Factors affecting concentrations of heavy metals in Athens Park soils}

The correlations of heavy metals determined in the present study are presented in Table 2. The statistically significant positive correlation between $\mathrm{Pb}-\mathrm{Zn}-\mathrm{Cu}$ is indicative of the common origin of these elements; they are typical anthropogenic elements related to traffic or point source emissions in the urban environment (Albanese and Breward, 2011). Also, the observed positive correlations between $\mathrm{Cr}-\mathrm{Ni}-\mathrm{Mn}$ points to their natural origin in Athens' soil. Specifically, $\mathrm{Cr}$, Ni and $\mathrm{Mn}$ are interpreted as geogenic elements associated with the ophiolithic parent rocks within the Athens Basin (Argyraki and Kelepertzis, 2014). Positive correlation coefficients were also observed between total and $\mathrm{HCl}$ extractable heavy metals with higher values for $\mathrm{Cu}, \mathrm{Zn}$ and $\mathrm{Pb}(0.826,0.793$ and 0.600 respectively) and lower, insignificant values for $\mathrm{Mn}, \mathrm{Ni}$ and $\mathrm{Cr}(0.444,0.332$ and 0.176 respectively). Furthermore, the organic carbon is positively correlated with the anthropogenic elements in both the extraction with $\mathrm{HCl}$ and the total digestion. However, the effect of organic carbon is far more pronounced for controlling the availability of $\mathrm{Pb}, \mathrm{Zn}, \mathrm{Cu}$ highlighting that soil organic matter effectively binds more heavy metals that are readily available in the applied leaching procedure. 


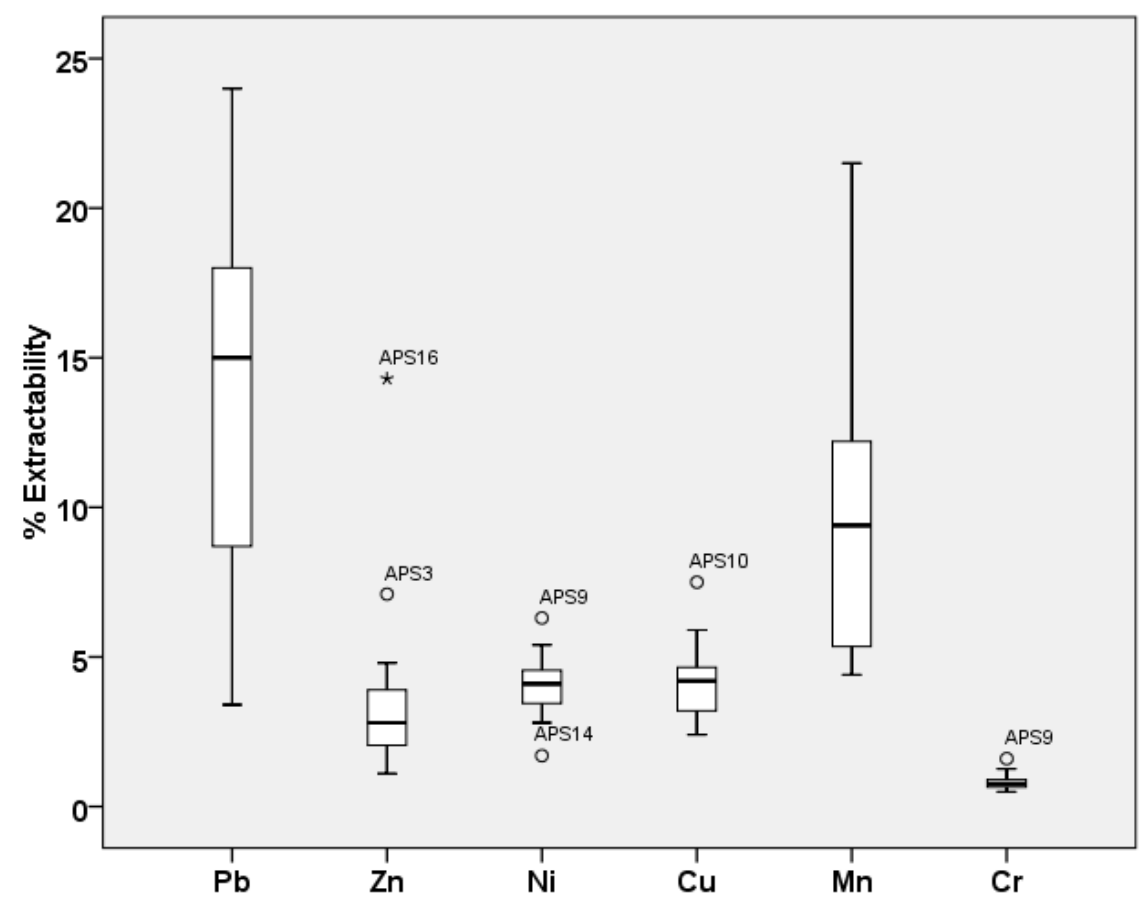

Figure 3 - Box plots of the extractability ratio for each heavy metal determined in soil samples $(n=20)$ from Athens parks. The length of the box indicates the interquartile range whereas the horizontal line within each box represents the median. Whiskers extend to the maximum and minimum data point within 1.5 box heights from the top and the bottom of the box. The star characters are the extreme values which are more than 3 times the interquartile range above the third quartile.

Table 2 - Correlations of the studied elements ( $\mathrm{Cr}, \mathrm{Ni}, \mathrm{Mn}, \mathrm{Pb}, \mathrm{Zn}, \mathrm{Cu})$.

\begin{tabular}{|l|l|l|l|l|l|l|}
\hline \multicolumn{7}{|c|}{ Total concentration data } \\
\hline & $\mathrm{Pb}$ & $\mathrm{Zn}$ & $\mathrm{Ni}$ & $\mathrm{Cu}$ & $\mathrm{Mn}$ & $\mathrm{Cr}$ \\
\hline $\mathrm{Pb}$ & 1.000 & & & & & \\
\hline $\mathrm{Zn}$ & $\mathbf{0 . 8 9 3}$ & 1.000 & & & & \\
\hline $\mathrm{Ni}$ & 0.132 & 0.215 & 1.000 & & & \\
\hline $\mathrm{Cu}$ & $\mathbf{0 . 8 5 0}$ & $\mathbf{0 . 7 3 8}$ & -0.006 & 1.000 & & \\
\hline $\mathrm{Mn}$ & 0.197 & 0.158 & 0.417 & 0.082 & 1.000 & \\
\hline $\mathrm{Cr}$ & 0.298 & 0.415 & $\boldsymbol{0 . 8 1 4}$ & 0.115 & $\mathbf{0 . 5 3 0}$ & 1 \\
\hline $\mathrm{TOC}$ & $\mathbf{0 . 7 5 9}$ & $\boldsymbol{0 . 6 7 3}$ & -0.111 & $\mathbf{0 . 5 3 6}$ & -0.056 & -0.180 \\
\hline \multicolumn{7}{|c|}{ HCl extractable concentration data } \\
\hline $\mathrm{Pb}$ & $\mathrm{Zn}$ & $\mathrm{Ni}$ & $\mathrm{Cu}$ & $\mathrm{Mn}$ & $\mathrm{Cr}$ \\
\hline $\mathrm{Pb}$ & 1.000 & \multicolumn{7}{|c|}{} & & & \\
\hline $\mathrm{Zn}$ & $\mathbf{0 . 7 2 5}$ & 1.000 & & & & \\
\hline $\mathrm{Ni}$ & 0.391 & $\mathbf{0 . 7 1 0}$ & 1.000 & & & \\
\hline $\mathrm{Cu}$ & $\mathbf{0 . 5 5 3}$ & $\mathbf{0 . 5 8 8}$ & 0.321 & 1.000 & & \\
\hline $\mathrm{Mn}$ & 0.442 & $\mathbf{0 . 8 6 6}$ & $\mathbf{0 . 7 3 7}$ & 0.491 & 1.000 & \\
\hline $\mathrm{Cr}$ & 0.009 & -0.007 & -0.057 & 0.152 & -0.016 & 1 \\
\hline $\mathrm{TOC}$ & $\mathbf{0 . 6 8 6}$ & $\mathbf{0 . 7 2 3}$ & -0.056 & $\mathbf{0 . 5 6 3}$ & 0.192 & -0.159 \\
\hline
\end{tabular}


Statistically significant higher concentrations of $\mathrm{Cu}, \mathrm{Pb}$, and $\mathrm{Zn}$ (anthropogenic elements) are detected in parks located in the centre of Athens and overpopulated areas (APS3, APS6, APS11, APS14, APS16, APS18-20) in comparison to suburban areas (APS1,2,4,5,7,8,10,12,13,15) (see Fig. 1 for sample location). This indicates that vehicular traffic is the major contributory factor in urban soil contamination by the typical anthropogenic elements (Li et al., 2001, 2004; Möller et al., 2005; Morton-Bermea et al., 2009; Andersson et al., 2010). Leaded fuel for $\mathrm{Pb}$ and its use as a balance in the wheels of the cars (Harris and Davidson, 2005) and tire wear for Zn have been recognized as specific vehicular traffic-related sources (Albanese and Breward, 2011). Higher concentrations in the central parks could also be related to the age of park and site history as well as the distance of the sampling location from heavy traffic roads. Such data are not available in this study.

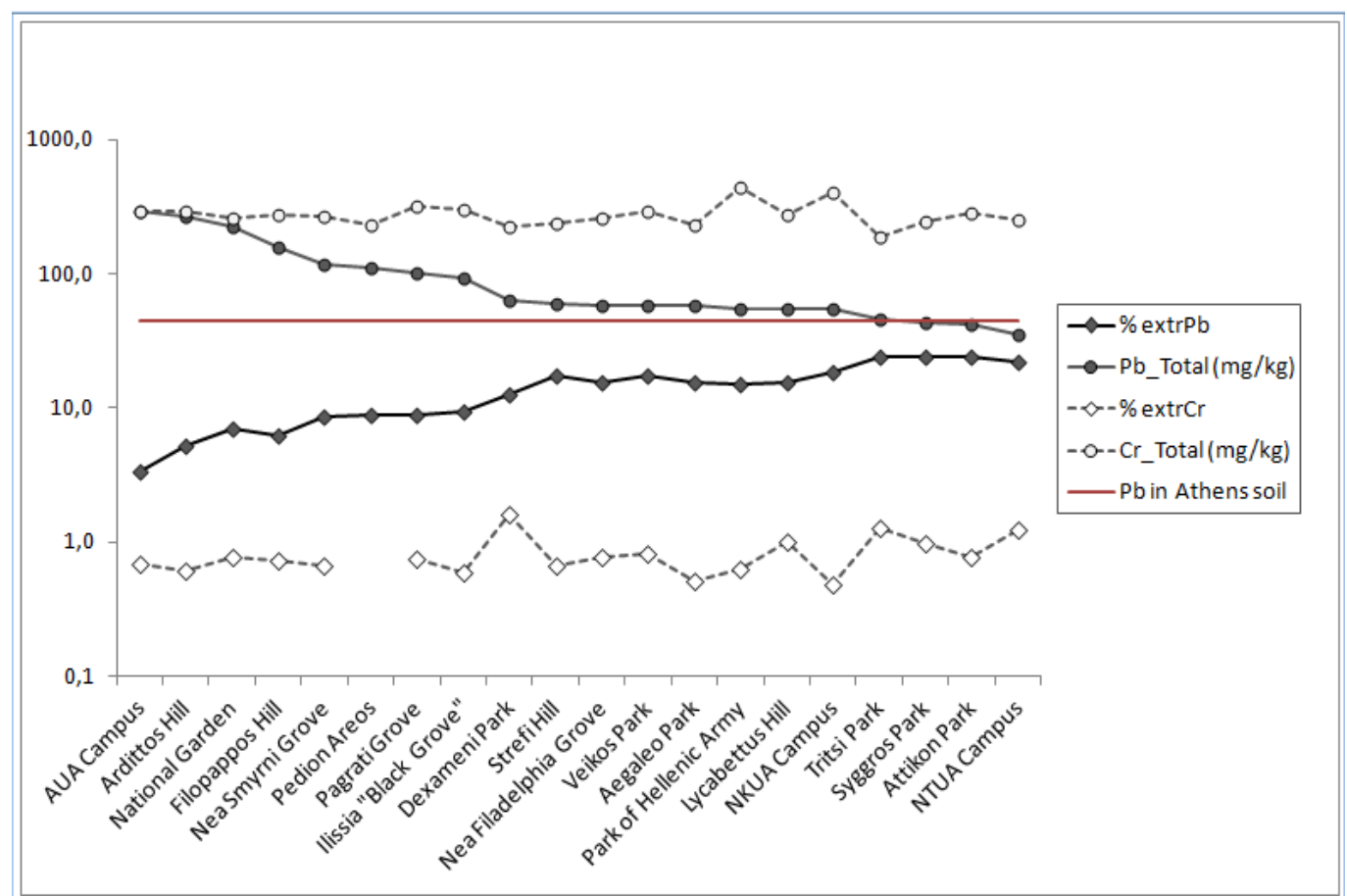

Figure 4 - Pattern of total and $1 \mathrm{M} \mathrm{HCl}$ extractable concentration of $\mathrm{Pb}$ (dark symbols) and $\mathrm{Cr}$ (white symbols) with respect to sample location. The continuous horizontal line corresponds to the median concentration $\left(45 \mathrm{mg} \mathrm{kg}^{-1}\right)$ of total $\mathrm{Pb}$ in Athens soil reported previously by Argyraki and Kelepertzis (2014).

A comparison based on data of $\mathrm{Pb}$ and $\mathrm{Cr}$ concentrations in Athens' park soils as examples of anthropogenic and geogenic elements respectively reveals interesting patterns, showing the influence of elemental origin on their extractability behaviour (Fig. 4). Chromium, as a geogenic element, is characterized by low lability, reflecting its fixation to more stable chemical forms. This, explains the relative uniform pattern for both total concentration and extractability percentage of $\mathrm{Cr}$ (which is also $<1 \%$ for most cases) resulting from the dissolution of rock forming minerals which are indifferent within the spatial scale of this study. In the instance of $\mathrm{Pb}$ a greater degree of variability is observed in both total concentrations and extractability ratios among the samples. Furthermore, only three samples have total $\mathrm{Pb}$ concentration lower than $45 \mathrm{mg} \mathrm{kg}^{-1}$ i.e. the median value previously reported for $\mathrm{Pb}$ in Athens top soil (Argyraki and Kelepertzis, 2014). This finding supports the hypothesis that top soil in park and woodland areas is enriched in airborne through either greater deposition (Ukonmaanaho et al., 2001; Michopoulos et al., 2005), or due to distinct point sources of pollution (Argyraki and Kelepertzis, 2014). Interestingly, samples from the parks with the highest total $\mathrm{Pb}$ concentrations demonstrate the lowest extractability ratios. Considering the 
significant positive correlation between $\mathrm{Pb}$ and organic carbon as well as between $\mathrm{Pb}$ and $\mathrm{Mn}$ in soil, this pattern probably underlines the role of effective binders of $\mathrm{Pb}$ in park top soils.

\section{Conclusions}

The total and extractable concentrations of $\mathrm{Pb}, \mathrm{Zn}, \mathrm{Ni}, \mathrm{Cu}, \mathrm{Mn}$ and $\mathrm{Cr}$ in soils from parks in Athens, Greece were investigated in this study. The soil samples show significant levels of $\mathrm{Ni}$ and $\mathrm{Cr}$ content in agreement with the high geochemical background of these elements in Athens. The mean and median concentrations of all studied elements were above the median values previously reported for Athens soil. Among the investigated heavy metals in the studied soils, $\mathrm{Mn}, \mathrm{Ni}$ and $\mathrm{Cr}$ are interpreted as geogenic and $\mathrm{Pb}, \mathrm{Zn}$ and $\mathrm{Cu}$ as anthropogenic, with $\mathrm{Pb}$ and $\mathrm{Mn}$ showing significantly higher dilute acid extractable concentrations than the other metals. The concentrations of $\mathrm{Pb}, \mathrm{Zn}$ and $\mathrm{Cu}$ were also more dependent on organic matter. The mobility of heavy metals determined in the present study by the $1 \mathrm{M} \mathrm{HCl}$ extraction follows the decreasing order: $\mathrm{Pb}>\mathrm{Mn}>\mathrm{Ni} \approx \mathrm{Cu} \approx \mathrm{Zn}>\mathrm{Cr}$. Our data indicate that vegetated areas within the urban net of Athens have a significant effect on the sequestration of the anthropogenic heavy metals in soil.

\section{References}

Ajmone-Marsan, F. and Biasioli, M., 2010. Trace elements in soils of urban areas, Water Air and Soil Pollution, 213, 121-43.

Albanese, S. and Breward, N., 2011. Sources of anthropogenic contaminants in the urban environment. Chapter 8. In: Johnson, C.C., Demetriades, A., Locutura, J. and Ottesen, R.T., eds., Mapping the chemical environment of urban areas, Chichester, U.K., John Wiley \& Sons, Ltd, 116-27.

Andersson, M., Ottesen, R.T. and Langedal, M., 2010. Geochemistry of urban soils - monitoring in Trondheim, Norway, Geoderma, 156,112-8.

Argyraki, A. and Kelepertzis, E., 2014. Urban soil geochemistry in Athens, Greece: The importance of local geology in controlling the distribution of potentially harmful trace elements, The Science of the Total Environment, 482-483, 366-377.

Cannon, W.F. and Horton, J.D., 2009. Soil geochemical signature of urbanization and industrialization - Chicago, Illinois, USA, Appl. Geochem., 24, 1590-601.

Chen, T-B., Zheng, Y.-M., Lei, M., Huang, Z.-C., Wu, H.-T., Chen, H., Fan, K.-K., Yu, K., Wu, X. and Tian, Q.-Z., 2005. Assessment of heavy metal pollution in surface soils of urban parks in Beijing, China, Chemosphere, 60, 542-51.

Gasparatos, D., Mavromati, G., Kotsovilis, P. and Massas, I., in press. Fractionation of heavy metals and evaluation of the environmental risks for the alkaline soils of the Thriassio plain: a residential, agricultural and industrial area in Greece, Environmental Earth Science, doi: http://dx.doi.org/10.1007/s12665-015-4096-1.

Harris, A.R. and Davidson, C.I., 2005. The Role of Resuspended Soil in Lead Flows in the California South Coast Air Basin, Environmental Science and Technology, 39(19), 7410-7415.

Kelepertzis, E. and Argyraki, A., 2015. Geochemical associations for evaluating the availability of potentially harmful elements in urban soils: Lessons learnt from Athens, Greece, Applied Geochemistry, 59, 63-73.

Kelepertzis, E. and Stathopoulou, E., 2013. Availability of geogenic heavy metals in soils of Thiva town (central Greece), Environmental Monitoring and Assessment, 185, 9603-9618.

Lacatusu, R., Breaban, I., Carstea, S., Lungu, M. and Bretan, A., 2007. Abundance of heavy metals in urban soils as concerns genesis and polluting impact, Scientific Paper Journal, Agronomy Series, 50, 141-149.

Lafuente, A.L., González, C., Quintana, J.R., Vázquez, A. and Romero, A., 2008. Mobility of heavy metals in poorly developed carbonate soils in the Mediterranean region, Geoderma, 145, 238-244.

Lee, C.S.I., Li, X., Shi, W., Cheung, S.Cn. and Thornton, I., 2006. Metal contamination in urban, suburban, and country park soils of Kong Kong: a study based on GIS and multivariate statistics, Sci. Total. Environ., 356, 45-61. 
Li, X., Lee, S.-L., Wong, S.-C., Shi, W. and Thornton, I., 2004. The study of metal contamination in urban soils of Hong-Kong using a GIS-based approach, Environ. Pollut., 129, 113-24.

Li, X., Poon, C.-S. and Liu, P.S., 2001. Heavy metal contamination of urban soils and street dusts in Hong Kong, Appl. Geochem., 16, 1361-8.

Madrid, L., Diaz-Barrientos, E. and Madrid, F., 2002. Distribution of heavy metal contents of urban soils in parks of Seville, Chemosphere, 49, 1301-1308.

Massas, I., Ehaliotis, C., Kalivas, D. and Panagopoulou, G., 2010. Concentrations and Availability Indicators of Soil Heavy Metals; the Case of Children's Playgrounds in the City of Athens (Greece), Water Air Soil Pollut., 212, 51-63.

Massas, I., Kalivas, D., Ehaliotis, C. and Gasparatos, D., 2013. Total and available heavy metal concentrations in soils of the Thriassio plain (Greece) and assessment of soil pollution indexes, Environmental Monitoring and Assessment, 185, 6751-66.

Michopoulos, P., Baloutsos, G., Economou, N., Nikolis, N., Bakeas, E.B. and Thomaidis, N.S., 2005. Biogeochemistry of lead in an urban forest in Athens, Greece. Biogeochemistry, 73, 345-57.

Mielke, H., Gonzales, C., Smith, M. and Mielke, P., 1999. The urban environment and children's health: soils as an integrator of lead, zinc and cadmium in New Orleans, Louisiana, USA. Environ. Res., 81, 117-129.

Möller, A., Müller, H.W., Abdullah, A., Abdelgawad, G. and Utermann, J., 2005. Urban soil pollution in Damascus, Syria: concentrations and patterns of heavy metals in the soils of the Damascus Ghouta, Geoderma, 124, 63-71.

Morton-Bermea, O., Hernández-Álvarez, E., González-Hernández, G., Romero, F., Lozano, R. and Beramendi-Orosco, L.E., 2009. Assessment of heavy metal pollution in urban topsoils from the metropolitan area of Mexico City, J. Geochem. Explor., 101, 218-24.

Pouyat, R., Yesilonis, I., Szlavecz, K., Csuzdi, C., Hornung, E., Korsós, Z., Russell-Anelli, J. and Giorgio, V., 2008. Response of forest soil properties to urbanization gradients in three metropolitan areas, Landscape Ecol., 23, 1187-1203.

Rasmussen, P., Subramanian, S. and Jessiman, B., 2001. A muti-elements profile of housedust in relation to exterior dust and soils in the city of Ottawa, Canada, The Science of the Total Environment, 267, 125-140.

Ukonmaanaho, L., Starr, M., Mannio, J. and Ruoho-Airola, T., 2001. Heavy metal budgets for two headwater forested catchments in background areas of Finland, Environ. Pollut., 114, 63-75.

US-EPA, 2002. Methods for the determination of total organic carbon (TOC) in soils and sediments, Report No. NCEA-C-1282, EMASC-001, Las Vegas.

VROM, 2000. Circular on target values and intervention values for soil remediation: DBO/1999226863, Netherlands Government Gazette, 39, 1-11.

Wong, C., Li, X. and Thorton, I., 2006. Review on urban environmental geochemistry of trace metals, Environmental Pollution, 142, 1-16.

Yaylali-Abanuz, G., 2011. Heavy metal contamination of surface soil around Gebze industrial area, Turkey, Microchemical Journal, 99, 82-92. 